\title{
Krzysztof Stachura
}

Instyłut Filozofii, Socjologii i Dziennikarstwa

Uniwersytet Gdański

e-mail: kastachura@gmail.com

\section{Nowe media i technologie tożsamości. Lifestreaming jako praktyka spoteczno-kulturowa}

DOI: $10.12775 /$ TSB. 2014.009

STRESZCZEnIE: Tekst poświęcony jest teoretycznej analizie zjawiska lifestreamingu - specyficznej praktyki społeczno-kulturowej zakorzenionej w realiach nowych technologii komunikacyjnych. Lifestreaming polega na pozostawianiu online cyfrowych śladów, transmitowaniu treści powiązanych z Ja, (auto)eksploracji własnej tożsamości przed usieciowioną publicznością. Za sprawą afordancji właściwych nowym technologiom komunikacyjnym ich użytkownicy mają możliwość dzielenia się z innymi różnorodnymi treściami i zarządzania swoją obecnością na platformach społecznościowych w sieciowych mediach mobilnych. W tekście przedstawione zostaje analityczne tło i społeczny kontekst opisywanej praktyki, jak również potencjalne scenariusze ewolucji badanego dziś na gruncie nauk społecznych zjawiska.

SŁowA KLUCzowe: (auto)eksploracja rzeczywistości; lifestreaming; nowe technologie komunikacyjne; reedytowanie Ja.

\section{Wprowadzenie}

O statnie lata to w naukach społecznych okres wzmożonej refleksji nad kulturowymi i obyczajowymi konsekwencjami wpływu nowych technologii na miejsce jednostki w społecznym krajobrazie. Pojawia się coraz więcej opracowań z zakresu antropologii czy socjologii mediów mobilnych, a ich oddźwięk, mierzony choćby liczbą i jakością głosów im 
poświęconych w dyskursie akademickim, znacznie wzrósł. Niewątpliwie wątek znaczenia nowych technologii, w tym tych mobilnych, stał się w naukach społecznych zagadnieniem istotnym. Zaczynamy też adaptować tematy i problemy badawcze dotychczas pomijane czy też nieopisywane z uwagi na fakt, że są to zjawiska nowe, relatywnie słabo rozpoznane analitycznie. Jednym z takich zagadnień jest zjawisko lifestreamingu, którego teoretycznemu opisowi poświęcony jest niniejszy tekst ${ }^{1}$.

Lifestreaming zdefiniować można na kilka sposobów. W szerokim rozumieniu jest to po prostu specyficzna praktyka społeczno-kulturowa, która manifestuje się poprzez aktywność podejmowaną online. Przyjmuje ona charakter strumienia zapośredniczonej, transmitowanej przez technologie aktywności społecznej; stanowi ciągły dopływ informacji o tym, co jednostka w danej chwili robi, gdzie jest i o czym myśli. Tym samym jest to charakterystyczne zestawienie cyfrowych śladów pozostawianych online, umożliwiające jednocześnie, zarówno osobom, które określone treści generują, jak i tym, które mogą się z nimi zapoznawać, rodzaj eksploracji Ja. Podobnie jak stosujący zaawansowane techniki analityczne metodolog drąży dane i pozyskuje na tej podstawie określoną wiedzę o badanej zbiorowości (ang. data mining), każdy użytkownik nowych technologii komunikacyjnych, przede wszystkim platform społecznościowych, ma potencjalną możliwość dokonania analogicznego zabiegu z danymi „tożsamościowymi” na publikowanych i udostępnianych online platformach (ang. reality mining).

Problematykę szeroko rozumianego lifestreamingu podejmowali w swoich pracach między innymi Erick Schonfeld ${ }^{2}$, Mizuko Ito ${ }^{3}$, Rich Ling ${ }^{4}$, a w największym stopniu i najbardziej kompleksowo - Alice Mar-

1 Należy na wstępie zaznaczyć, że tytułowy lifestreaming nie doczekał się jak dotąd swojego polskiego odpowiednika. W dalszej części tekstu autor precyzuje, na czym owo zjawisko polega, próbując dookreślić jego znaczenie. Z uwagi na eksploracyjny charakter relacjonowanego studium autor proponuje jednak nie tłumaczyć go jeszcze wprost na język polski, inicjując jedynie poświęconą tej kwestii debatę.

2 E. Schonfeld, Mining the Thought Stream. „TechCrunch” [online] February 15, 2009 [dostęp 31 maja 2014]. Dostępny w World Wide Web: http://techcrunch.com/2009/02/15/mining-the-thought-stream/.

3 Personal, Portable, Pedestrian: Mobile Phones in Japanese Life, ed. by M. Ito, M. Matsuda, D. Okabe, Cambridge 2006.

${ }^{4}$ R. Ling, New Tech, New Ties: How Mobile Communication is Reshaping Social Cohesion, Cambridge 2008. 
wick . Pośrednio tą tematyką interesuje się większa liczba badaczy. Poza socjologami i antropologami należy zaliczyć do tego grona kulturoznawców i geografów społecznych. Uwaga uczonych skoncentrowana jest na szeregu powiązanych z lifestreamingiem zagadnień, takich jak przestrzenie hybrydowe ${ }^{6}$, media lokacyjne ${ }^{7}$, intymność w tle ${ }^{8}$, mobilne kultury afektywne ${ }^{9}$ czy rzeczywistość wzmocniona ${ }^{10}$. Zasadnicze znaczenie dla rozwoju praktyk o charakterze lifestreamingowym mają z jednej strony stały rozwój Internetu 2.0, społeczny charakter wielu platform online, umożliwiających nawiązywanie kontaktów z innymi i zarządzanie publikowanymi treściami, z drugiej zaś - silna ewolucja ku mobilności. Interfejsy urządzeń przenośnych pozwalają z dużą łatwością poruszać się w przestrzeni online. Są często bardziej intuicyjne niż poprzedzające je wersje desktopowe (stacjonarne) wielu serwisów i aplikacji społecznościowych i, co najważniejsze, dają użytkownikom możliwość permanentnego podłączenia do sieci.

\section{Zarzq̨dzanie Ja w realiach medialnego zapośredniczenia}

Chcąc opisać specyfikę lifestreamingu jako praktyki społeczno-kulturowej, należy uwzględnić teoretyczne tło zmian, jakie obserwujemy w związku

5 A. E. Marwick, Status Update: Celebrity, Publicity and Self-Branding in Web 2.0 [online]. New York: New York University, Department of Media, Culture, and Communication, 2010, 511 s. [dostęp 31 maja 2014]. Dostępny w World Wide Web: http://www.tiara. org/blog/wp-content/uploads/2010/09/marwick_dissertation_statusupdate.pdf.

${ }_{6}$ Zob. np. A. de Souza e Silva, From Cyber to Hybrid. Mobile Technologies as Interfaces of Hybrid Spaces, „Space and Culture” 2006, Vol. 9, No. 3, s. 261-278.

7 Zob. np. J. G. Hamilton, Ourplace: The Convergence of Locative Media and On-line Participatory Culture [online]. QUT Digital Repository [dostęp 31 maja 2014]. Dostępny w World Wide Web: http://eprints.qut.edu.au/29702/1/c29702.pdf.

${ }^{8}$ Zob. np. L. Reichelt, Ambient Intimacy. „Disambiguity” [online] March 1, 2007 [dostęp 31 maja 2014]. Dostępny w World Wide Web: http://www.disambiguity.com/ ambient-intimacy.

9 Zob. np. K. Kopecka-Piech, Mobilne media miejskie, „Studia Medioznawcze” 2012, nr 3, s. 111-125.

10 Zob. np. E. Ruppert, J. Law, M. Savage, Reassembling Social Science Methods: The Challenge of Digital Devices, „Theory, Culture, Society” 2013, Vol. 30, No. 4, s. 22-46; T. O’Reilly, J. Pahlka, The 'Web Squared' Era. „Forbes” [online] 24.09.2009 [dostęp 31 maja 2014]. Dostępny w World Wide Web: http://www.forbes.com/2009/09/23/web-squaredoreilly-technology-breakthroughs-web2point0.html. 
z ekspansją nowych technologii komunikacyjnych. Relacyjny charakter współczesności wyznaczony jest przez już nadrzędną, ale jednocześnie stale rosnącą rolę mobilnych mediów w procesach konstruowania i rekonstruowania więzi społecznych. Przypisane mediom afordancje komunikacyjne, czyli możliwości, jakie wynikają z ich używania i właściwe im potencjały, mają istotny wpływ na podejmowane przez aktorów społecznych strategie zarządzania Ja oraz koordynacji relacji z innymi. W praktyce oznacza to, że znaczna część ludzkiej aktywności i kontaktów ulega zapośredniczeniu. Komunikacja toczy się jednocześnie online i offline, w świecie zespolonym, w którym różne od siebie przestrzenie składają się w jedną, zazwyczaj spójną całość. Przestajemy więc mówić o dwóch rzeczywistościach i przyzwyczajamy się, by mówić o jednej, rozszerzonej. W tak zdefiniowanych realiach nowym technologiom komunikacyjnym przypada rola kluczowej platformy społecznej, która, choć wywołuje niekiedy niezamierzone efekty desocjalizacyjne ${ }^{11}$, przede wszystkim umożliwia sprawniejsze formy bycia w kontakcie z innymi, w tym te formy komunikacji, w których to jednostka jest centrum świata społecznego, aktorem sprawczym, generującym strumień danych powiązanych z Ja.

Pojawienie się nowych wzorów społecznej organizacji jest równoznaczne z wystąpieniem nowych modeli uspołecznienia - bardziej otwartych i w większej niż dawniej mierze społecznie konstruowanych. Te wyłaniające się, nieostre w założeniu formy czekają na nadanie im treści i to zadanie należy właśnie do jednostki stawiającej sobie za cel odnajdywanie sensów dla swojej obecności w świecie społecznym, a w efekcie prowadzenie satysfakcjonującego życia. Choć miara tej satysfakcji jest rzecz jasna różna, znaczenie ma fakt, że w coraz większym stopniu sensotwórcze stają się maszyny, jakimi są platformy komunikacyjne, serwisy społecznościowe i aplikacje mobilne. I to je wykorzystuje się dziś, by (re)konstruować i nadawać nowe znaczenia Ja. Konieczny staje się więc namysł nad tym, co de facto mogą zaoferować nowe technologie komunikacyjne oraz z jakich ich możliwości i dlaczego - mimo właściwych ich logice niepewności i efemeryczności - tak chętnie się korzysta.

Mediatyzacja świata społecznego oznacza konieczność stworzenia nowej ramy pojęciowej, określającej sposoby funkcjonowania w świecie

11 L. Fortunati, S. Taipale, F. de Luca, What Happened To Body-to-body Sociability?, „Social Science Research” 2013, Vol. 42, No. 3, s. 893-905. 
zapośredniczonym przez nowe technologie. Niezbędna jest między innymi zmiana sposobu myślenia o tym, czym jest bycie online i jak (inaczej) rozumieć pozostawanie podłączonym do sieciowych zasobów. Z jednej strony mamy bowiem do czynienia, głównie za sprawą technologii mobilnych, z możliwością permanentnego śledzenia przepływów interakcji i komunikatów w mediach społecznych, z drugiej zaś to właśnie trend ku mobilności sprawił, że nieaktualna jest już chętnie dotychczas stosowana definicja tzw. heavy users, czyli użytkowników, którzy poświęcają przynajmniej kilka godzin na bycie online. Czas poświęcany na korzystanie z nowych technologii komunikacyjnych jest oczywiście istotnym czynnikiem w dyskursie o strategiach używania nowych mediów, ale traci na znaczeniu w kontekście coraz silniej wykorzystywanej możliwości stałego generowania online różnych treści, kontaktów i emocji oraz śledzenia tego rodzaju aktywności przez innych.

Mobilne media stały się, jak sugeruje Michał Wanke, bardziej przezroczyste, w większym stopniu refleksyjne i spersonalizowane. Za ich pośrednictwem więcej można zobaczyć i odczytać (także przesłanek tożsamościowych). Są interaktywne, przez co wymagają od jednostek użytkowników określonej dozy sprawstwa, a sami użytkownicy dostosowują je do własnych potrzeb i korzystają z możliwości ich konfiguracji ${ }^{12}$. Zmiany te w praktyce oznaczają między innymi to, że jednostki korzystają z możliwości generowania różnych komunikatów dotyczących Ja. Może to być relacjonowanie swojej codzienności, sprawozdawanie stanów emocjonalnych, sygnalizowanie potrzeby afiliacji czy też dzielenie się doświadczeniami i spostrzeżeniami na dowolny, ważny w danym momencie temat. Co więcej, powstaje coraz więcej narzędzi dobrze dostosowanych do generowania strumieni danych powiązanych z Ja, aplikacji i usług zapewniających możliwość pozostawiania po sobie cyfrowych śladów. W konsekwencji dochodzi do splecenia realiów online i offline w nową, choć trudną do zdefiniowania w przestrzeni i czasie sferę doświadczeń.

Nomadyczny charakter życia społecznego, wyznaczony między innymi upłynnieniem kontekstów komunikacyjnych i silniejszym powiązaniem ich z mobilnym wymiarem rzeczywistości, sprawia, że jednostki

${ }^{12} \mathrm{M}$. Wanke, Internet i nowe indywidualne i masowe formy uczestnictwa [online]. Slideshare [dostęp 31 maja 2014]. Dostępny w World Wide Web: http://www.slideshare. net/wankz/internet-i-nowe-indywidualne-i-masowe-formy-uczestnictwa. 
muszą sobie radzić z problemem dyslokacji i niestałych przynależności do ledwie zarysowanych miejsc. Reakcją na tę trudność jest entuzjastyczna postawa „wychodzenia do ludzi”, jednak bez pewności, gdzie ich można spotkać i na jakich warunkach takie spotkanie miałoby się właściwie odbyć1 ${ }^{13}$. Być może, jak sugeruje John Urry, trafiamy na siebie jako na „hybrydowych obcych” ${ }^{14}$, próbując synchronizować nasze wzajemne oczekiwania interakcyjne, ale jednocześnie nie rezygnując z woli pozostania centrum własnej sieci społecznej. W realiach otwartego, podlegającego nieznacznym sankcjom uspołecznienia jednostka zarządza wieloma doświadczeniami relacji z innymi właśnie za sprawą mediów społecznych. Koordynuje specjalnie w tym celu obrane strategie komunikacyjne, $\mathrm{w}$ tym pomysł na to, o czym, jak i dlaczego innych informować oraz z kim i w jakich warunkach pozostawać w kontakcie ${ }^{15}$.

Zarządzając nie tylko własną tożsamością, ale i do pewnego stopnia także współobecnością, jednostka zyskuje stopniowo świadomość złudnego podziału na to, co publiczne i prywatne. Te różnice oczywiście istnieją, ale są dużo bardziej zniuansowane, niż wynikałoby z dychotomicznego podziału. Praktyka bycia online oznacza zazwyczaj konieczność przełączania kontekstów prywatności, dostosowywania ich do określonych realiów sytuacyjnych i rozumienia, jak trudna do uchwycenia jest struktura usieciowionych publiczności. Rozróżnianie na prywatne i publiczne, umiejętność stopniowania i dostrzegania odcieni tych dwóch biegunowo zdefiniowanych cech wymaga znacznej biegłości w odczytywaniu znaczeń tego, co dzieje się online i nieodwołalnie prowadzi do mniejszych bądź większych napięć. Dzieje się tak także dlatego, że kontaktów, w które jednostka angażuje się online, jest zazwyczaj dużo, a interakcje mają acielesny, pozbawiony materialności charakter.

Do zarysowanych trudności dochodzi jeszcze wspominany przez Zygmunta Baumana fakt, że sieć jest przestrzenią, w której powstają wspólnoty szatniowe ${ }^{16}$ - zbyt przelotne i za słabo ustrukturyzowane, by trwać,

13 R. N. Bellah, R. Madsen, W. M. Sullivan, A. Swidler, S. M. Tipton, Skłonności serca. Indywidualizm i zaangażowanie po amerykańsku, Warszawa 2007, s. 67, 85.

14 J. Urry, Mobility and Proximity, „Sociology” 2002, Vol. 36, No. 2, s. 267.

15 L. Rainie, B. Wellman, Networked: The New Social Operating System, Cambridge 2012.

16 Z. Bauman, Żyjąc w czasie pożyczonym, Kraków 2010, s. 115-124. 
a co za tym idzie, nieść faktyczne korzyści dla swoich członków. Umożliwiany przez nowe, mobilne media stan synchronizacji i momentalnej wszechobecności prowadzić może, idąc za sugestią Kennetha J. Gergena, do stanu nadmiernego nasycenia Ja, multifrenii, przesytu bodźców i możliwości, które - choć łatwe do pozyskania, bo znajdujące się w zasięgu ręki - jednocześnie od siebie uzależniają ${ }^{17}$. Sherry Turkle podsumowałaby ten krytyczny dyskurs o relacyjnym potencjalne nowych technologii komunikacyjnych tezą o skutkującej cybersamotnością ekspansji reżimu konektywności ${ }^{18}$, skądinąd kluczowej, by w ogóle analizować to, na czym polegają praktyki lifestreamingowe.

\section{Lifestreaming, czyli jak reedytować się we wzmocnionej rzeczywistości}

Uzupełniając przedstawiony na wstępie kontekst definicyjny lifestreamingu, warto dookreślić, kto zalicza się do grona osób, które tę praktykę aktywnie podejmują. Wprawdzie trudno wyodrębnić uniwersalne kryteria, które pozwalają jednoznacznie zaklasyfikować danego użytkownika mediów społecznych do badanej grupy, ale można wskazać cechy, na podstawie których takie rozróżnienie staje się łatwiejsze. Lifestreaming oznacza intensywne korzystanie z nowych technologii komunikacyjnych, często też obecność na więcej niż jednej platformie społecznościowej. Wymaga od użytkowników określonej dozy technologicznej świadomości, czy też znajomości środowiska nowych technologii - wysoki poziom refleksji w tych kwestiach często koreluje z ilością generowanego strumienia danych dotyczących Ja. Wiele osób decydujących się świadomie na (systematyczne) relacjonowanie swojego życia online wykorzystuje w tym celu aplikacje i narzędzia mobilne. Można uznać, że esencją lifestreamingu jest zdolność i chęć relacjonowania zdarzeń życiowych w dużej mierze niezależnie od lokalizacji, w jakiej się aktualnie prze-

17 K. Gergen, Nasycone Ja. Dylematy tożsamości w życiu współczesnym, Warszawa 2009, s. 205-231.

${ }^{18}$ S. Turkle, Alone Together. Why We Expect More from Technology and Less from Each Other, New York 2011. 
bywa, co jest możliwe właśnie dzięki znacznemu umobilnieniu form komunikacji. Istotne znaczenie ma też specyficzna zdolność nadawania zwyczajnym zdarzeniom statusu niezwykłości, np. zamieszczanie zdjęć remontu mieszkania, opisywanie przyrządzania posiłków czy dzielenie się emocjami z koncertu.

Zestaw aplikacji, które pozwalają na generowanie i publikowanie online treści, stale ulega modyfikacjom. Z czasem liczba platform umożliwiających lifestreaming wzrasta, bo w miejsce narzędzi, które przestają cieszyć się popularnością, pojawia się jeszcze większa liczba nowych, często lepiej dostosowanych do potrzeb potencjalnych użytkowników.

Można wyróżnić siedem typów aplikacji czy platform, za pośrednictwem których zamieszcza się online różnego rodzaju treści (zarówno tekstowe, jak i audiowizualne), przy czym należy uwzględniać fakt, że niektóre $\mathrm{z}$ wymienionych narzędzi pełnią funkcję jednocześnie kilku wyróżnionych typów aplikacji bądź platform.

Tabela 1. Aplikacje i platformy umożliwiające lifestreaming

\begin{tabular}{|l|c|}
\hline \multicolumn{1}{|c|}{ TYP APLIKACJI / PLATFORMY } & PRZYKLAD APLIKACJI / PLATFORMY \\
\hline Serwis społecznościowy & Facebook, Google+ \\
\hline Serwisy mikroblogowe & Twitter, Tumblr \\
\hline Serwisy z materiałami wizualnymi & Pinterest, Instagram, Vine \\
\hline Serwisy z muzyką cyfrową & Soundcloud, Spotify, Last.fm \\
\hline Serwisy oparte na geolokalizacji & Foursquare, Glympse, Grindr \\
\hline Serwisy monitorujące aktywność sportową & Endomondo \\
\hline Serwisy ocen usług (ang. ratingowe) & Yelp \\
\hline
\end{tabular}

Źródło: opracowanie własne.

W dużej mierze niezależnie od typu platform wykorzystywanych do tego, by zamieszczać w ich obrębie treści, wyróżnić można dwa odrębne typy strumieni danych powiązanych z Ja. Pierwszy z nich - egocentryczno-tożsamościowy - ma charakter bardziej prywatny i intymny i jest związany z wydarzeniami, do jakich dochodzi w przestrzeni życia codziennego. Drugi natomiast - instrumentalno-zawodowy - zogniskowany jest wokół kwestii związanych z pracą i między innymi dlatego w większej 
mierze dba się, by sprawiał wrażenie fachowości i był przeznaczony dla szerokiej, anonimowej publiczności.

Autorka interesującego studium poświęconego praktykom upubliczniania Ja i określenia swojego statusu online, Alice Marwick, uważa, że lifestreaming jest rodzajem niematerialnej pracy emocjonalnej, formą uważnego reedytowania Ja. Opiera się na agregowaniu i autokwantyfikacji cyfrowych części Ja, przy czym konsekwencje tego procesu są dwojakie. Po stronie pozytywów Marwick wymienia przede wszystkim poprawę relacji interpersonalnych i wzrost pozycji społecznej. Obecność online może więc mieć zasadnicze znaczenie dla zwiększenia poziomu dobrostanu psychicznego oraz kapitału społecznego jednostki. Pozytywne konsekwencje równoważone są przez pojawiające się w efekcie podejmowania praktyki lifestreamowania trudności w zarządzaniu prywatnością i związane z tym poczucie cyfrowego nadzoru, a także generalnie zwiększony poziom stresu ${ }^{19}$.

Dla wielu osób, w szczególności młodych, publiczna artykulacja Ja stanowi ważny wymiar ich tożsamości. Badając wzory odkrywania i ujawniania informacji na swój temat wśród studentów, Zeynep Tufekci jako jedna z pierwszych badaczek doszła do wniosku, że w określonych grupach i środowiskach istnieje silna potrzeba wykorzystywania nowych technologii komunikacyjnych, by oznajmiać innym swoje stany emocjonalne, zainteresowania czy poglądy i by ten proces miał charakter regularny i trwały ${ }^{20}$. Nowego znaczenia w tym kontekście nabiera klasyczna już, formułowana ponad 50 lat temu myśl Marshalla McLuhana o mediach (w tym przypadku nowych mediach mobilnych / platformach społecznościowych) jako o przedłużeniu zmysłów. Ludzie - w szczególności młodzi - bywają specyficznie związani, by nie powiedzieć zrośnięci z urządzeniami, które zapewniają im podłączenie do sieci społecznych i często trudno im w ogóle wyobrażać sobie, że nie mogą skorzystać z możliwości zakomunikowania czegoś innym czy skontaktowania się $\mathrm{z} \mathrm{nimi}^{21}$.

19 A. Marwick, dz. cyt.

20 Z. Tufekci, Can You See Me Now? Audience and Disclosure Regulation in On-line Social Network Sites, „Bulletin of Science, Technology \& Society” 2008, Vol. 28, No. 1, s. 20-36.

${ }^{21}$ Zob. K. Stachura, Jak porzucić codzienny rytuat, czyli 24 godziny bez mediów, [w:] Kreacje i nostalgie. Antropologiczne spojrzenie na tradycje w nowoczesnych kontekstach, 
Po kilku latach od opublikowania badań Tufekci rozumienie tych dążeń jest nadal umiarkowane. Dyskurs wokół potrzeby generowania strumieni aktywności powiązanych z Ja, a następnie publikowania ich online jest przedmiotem krytycznych debat, przede wszystkim w szeroko rozumianym dyskursie publicznym. Przyglądając się manifestacjom tego dyskursu w Polsce, uwagę zwracają teksty artykułów w prasie społeczno-politycznej o takich tytułach, jak „Świergot zdechłej wrony”22, „Fejs-frustracja”23 czy „Słit focia z leżingu”24, których tezy krążą wokół szkodliwości korzystania z mediów społecznych, ich ogólnej nieprzydatności czy wręcz dysfunkcjonalności. Obecność zasygnalizowanej krytyki jest ważna dla charakteru ewolucji samej praktyki. Uznawany za niepoważny, a niekiedy groźny lifestreaming rozwija się niejako wbrew powszechnemu społecznemu oczekiwaniu, siłą sprawstwa aktorów decydujących się podejmować tego rodzaju aktywność.

Niezależnie od społecznego kontekstu praktyki, jej studiowanie ogniskuje się dziś wokół pytania o jakość i charakter zaangażowania jednostek w życie mobilnych platform społecznościowych. Studia nad lifestreamingiem powinny zmierzać do poszukiwania wyjaśnień, jaki rodzaj organizacji społecznej oferuje ten typ styczności - tak z interfejsem danego medium, jak i z innymi użytkownikami. Publikowane online i powiązane z Ja treści składają się na coraz bardziej gęste, sieciowe repozytoria codzienności, z którymi użytkownicy się wiążą i dla których te zbiory mają duże znaczenie (symboliczne, emocjonalne, ale i materialne).

Problematyczny staje się natomiast fakt, że towarzyszące silnej chęci zasygnalizowania swojej obecności niepisane „prawo do bycia zapomnianym" przestaje być pewne i oczywiste. W sieci treści, kontaktów i interakcji online dochodzi do wybuchającego raz po raz konfliktu mię-

pod red. D. Rancew-Sikory, G. Woronieckiej, C. Obracht-Prondzyńskiego, Warszawa 2009, s. $360-371$.

22 Z. Domaszewicz, Świergot zdechłej wrony. „Polityka” [online] 5.06.2009 [dostęp 31 maja 2014]. Dostępny w World Wide Web: http://www.polityka.pl/nauka/komputeryiinternet/293142,1,swiergot--zdechlej-wrony.read.

${ }^{23}$ G. Lewicki, Fejs-frustracja. „Wprost” [online] 2013, nr 37 [dostęp 31 maja 2014]. Dostępny w World Wide Web: http://www.wprost.pl/ar/415948/Fejs-frustracja/.

24 A. Krzyżaniak-Gumowska, Stit focia z lemingu. „Newsweek” [online] 2013, nr 30 [dostęp 31 maja 2014]. Dostępny w World Wide Web: http://polska.newsweek.pl/slitfocia-z-lezingu,106602,1,1.html. 
dzy oczekiwaniami użytkowników a interesami szefów platform gromadzących cenne dane o swoich klientach. Lifestreaming rozwija się wraz z ewolucją nowych technologii komunikacyjnych ku cyberpanoptyczności, poczuciu sprawowania kontroli nad treściami, jakie trafiają online przez często niezidentyfikowanych aktorów instytucjonalnych. Nie bez znaczenia jest tu fakt, że jakość sprawowanej kontroli nad strumieniem czy strumieniami danych, jakie ostatecznie trafiają w przestrzeń mediów społecznych, zależy w dużej mierze od skali kompetencji, jakimi dysponują poszczególni użytkownicy.

\section{Scenariusze na przyszłość}

Niejako zamiast podsumowania warto, w oparciu o przedstawione w tekście teoretyczne przemyślenia, rozważyć potencjalne możliwości ewolucji lifestreamingu jako praktyki społeczno-kulturowej, analizując przy tym możliwe skutki i konsekwencje manifestowania i reedytowania Ja online. Jednocześnie należy zastrzec, że postawienie bardziej dokładnych hipotez czy formułowanie bardziej precyzyjnych przewidywań byłoby możliwe po wykonaniu pracy z zebraną uprzednio odpowiednią ilością materiału empirycznego.

Jednym z możliwych scenariuszy ewolucji lifestreamingu jest kultura narcyzmu 2.0, tj. nowej wersji postawy, o której w latach 70. pisał Christopher Lasch ${ }^{25}$. Za sprawą afordancji nowych technologii komunikacyjnych rozwinąć mógłby się specyficzny typ jednostkowego samozadowolenia i przekonania o własnej wyjątkowości. Publikowanie powiązanych z Ja treści skutkowałoby chęcią kompulsywnego potwierdzania swojego statusu online, oczekiwaniem na natychmiastowe zaspokajanie potrzeb i pragnieniem doceniania własnej aktywności i twórczości w ponadprzeciętnym wymiarze. Miejsce spontanicznej konektywności zajęłyby nerwowa kompulsja i poczucie pustki powodowane koniecznością wyciszenia swojej aktywności i zmniejszenia koncentracji na Ja. Możliwość otwartego kontaktu wpisana w logikę komunikacji z wykorzystaniem

25 Zob. C. Lasch, The Culture of Narcissism: American Life in An Age of Diminishing Expectations, New York 1991. 
sieciowych platform społecznościowych zostałaby zastąpiona filtrowaną, symulowaną otwartością, w praktyce zaś brakiem możliwości nawiązania bliższych więzi za sprawą nowych technologii.

Zupełnie odmiennym scenariuszem byłaby za to kapitalizacja potencjału emancypacyjnego, uruchomionego w oparciu o praktykę lifestreamowania ${ }^{26}$. Odpowiednie wykorzystanie nowych technologii oferuje jej użytkownikom poczucie celowości i sprawstwa. Powoduje, że takie osoby zyskują większą pewność siebie, są zdolne artykułować swoje opinie, bronić własnego zdania i podejmować twórczą aktywność. Te procesy mogą zostać uruchomione także wtedy, gdy chodzi o aktywność z pozoru trywialną i nieistotną, jak choćby zamieszczanie linków do ulubionych piosenek na profilu w serwisie społecznościowym czy relacjonowanie prozaicznych wydarzeń z życia codziennego. Nawet jeśli nie przeradzają się w bardziej dojrzałe formy generowania treści online, mogą przyczyniać się do rozwoju zdolności refleksyjnego wyrażania własnego Ja. W przypadku gotowości użytkowników do poszerzania pola wątków transmitowanych online oraz współwystępującej aprobaty dla lifestreamowania możliwe byłoby również budowanie w ten sposób kapitału społecznego, w tym kapitału obywatelskości.

Wraz z ewolucją lifestreamingu jako praktyki społeczno-kulturowej prawdopodobnie obserwować będzie można współwystępowanie trendów - narcystycznego i emancypacyjnego. Ewolucja lifestreamingu będzie też prawdopodobnie oznaczać, że część osób porzuci ten rodzaj aktywności; zdecyduje się wylogować i odłączyć od sieci społecznych, których stanowi część. Dominację ustanowi jednak zapewne grono użytkowników gotowych, by dodawać online nowe warstwy informacji na swój temat, próbując optymalizować w ten sposób Ja. Taka forma organizacji czy też projektowania swojego życia ma nadać mu, w czasach rozmycia i niepewności, choć częściowo określoną strukturę.

${ }^{26}$ Jeśli ten scenariusz ziściłby się, to zapewne w dużej mierze wbrew techno-pesymistycznym przekonaniom, jakoby niedobór czy brak prywatności (na który dobrowolnie decydują się osoby generujące online treści powiązane z Ja) miał negatywny, ubezwłasnowolniający wpływ na funkcjonowanie jednostki w świecie społecznym. Zob. np. D. Brin, The Transparent Society: Will Technology Force Us To Choose Between Privacy And Freedom?, New York 1998. 


\section{Bibliografia}

Bauman Zygmunt, Żyjąc w czasie pożyczonym, Kraków 2010.

Bellah Robert N., Madsen Richard, Sullivan William M., Swidler Ann, Tipton Steven M., Skłonności serca. Indywidualizm i zaangażowanie po amerykańsku, Warszawa 2007.

Brin David, The Transparent Society: Will Technology Force Us To Choose Between Privacy And Freedom?, New York 1998

Domaszewicz Zbigniew, Świergot zdechłej wrony. „Polityka” [online] 5.06.2009 [dostęp 31 maja 2014]. Dostępny w World Wide Web: http://www.polityka. pl/nauka/komputeryiinternet/293142,1,swiergot--zdechlej-wrony.read.

Fortunati Leopoldina, Taipale Sakari, Luca Federico de, What Happened to Bodyto-body Sociability?, „Social Science Research” 2013, Vol. 42, No. 3, s. 893-905 .

Gergen Kenneth, Nasycone Ja. Dylematy tożsamości w życiu współczesnym, Warszawa 2009.

Hamilton Jillian G., Ourplace: The Convergence of Locative Media and On-line Participatory Culture [online]. QUT Digital Repository [dostęp 31 maja 2014]. Dostępny w World Wide Web: http://eprints.qut.edu.au/29702/1/ c29702.pdf.

Kopecka-Piech Katarzyna, Mobilne media miejskie , „Studia Medioznawcze” 2012, nr 3, s. 111-125.

Krzyżaniak-Gumowska Aleksandra, Stit focia z lemingu. „Newsweek” [online] 2013, nr 30 [dostęp 31 maja 2014]. Dostępny w World Wide Web: http:// polska.newsweek.pl/slit-focia-z-lezingu,106602,1,1.html.

Lewicki Grzegorz, Fejs-frustracja. „Wprost” [online] 2013, nr 37 [dostęp 31 maja 2014]. Dostępny w World Wide Web: http://www.wprost.pl/ar/415948/ Fejs-frustracja/.

Ling Rich, New Tech, New Ties: How Mobile Communication is Reshaping Social Cohesion, Cambridge 2008.

Marwick Alice E., Status Update: Celebrity, Publicity and Self-Branding in Web 2.0 [online]. New York: New York University, Department of Media, Culture, and Communication, 2010, 511 s. [dostęp 31 maja 2014]. Dostępny w World Wide Web: http://www.tiara.org/blog/wp-content/uploads/2010/09/ marwick_dissertation_statusupdate.pdf. 
O'Reilly Tim, Pahlka Jennifer, The 'Web Squared' Era. „Forbes” [online] 24.09.2009 [dostęp 31 maja 2014]. Dostępny w World Wide Web: http://www.forbes.com/2009/09/23/web-squared-oreilly-technology-breakthroughsweb2point0.html.

Personal, Portable, Pedestrian: Mobile Phones in Japanese Life, ed. by Mizuko Ito, Misa Matsuda i Daisuke Okabe, Cambridge 2006.

Rainie Lee, Wellman Barry, Networked: The New Social Operating System, Cambridge 2012.

Reichelt Leisa, Ambient Intimacy. „Disambiguity” [online] March 1, 2007 [dostęp 31 maja 2014]. Dostępny w World Wide Web: http://www.disambiguity. com/ambient-intimacy.

Ruppert Evelyn, Law John, Savage Mike, Reassembling Social Science Methods: The Challenge of Digital Devices, „Theory, Culture, Society” 2013, Vol. 30, No. 4, s. 22-46.

Schonfeld Erick, Mining the Thought Stream. „TechCrunch” [online] February 15, 2009 [dostęp 31 maja 2014]. Dostępny w World Wide Web: http:// techcrunch.com/2009/02/15/mining-the-thought-stream/.

Souza e Silva Adriana de, From Cyber to Hybrid. Mobile Technologies as Interfaces of Hybrid Spaces, „Space and Culture” 2006, Vol. 9, No. 3, s. 261-278.

Stachura Krzysztof, Jak porzucić codzienny rytuał, czyli 24 godziny bez mediów, [w:] Kreacje i nostalgie. Antropologiczne spojrzenie na tradycje w nowoczesnych kontekstach, pod red. Doroty Rancew-Sikory, Grażyny Woronieckiej, Cezarego Obracht-Prondzyńskiego, Warszawa 2009, s. 360-371.

Tufekci Zeynep, Can You See Me Now? Audience and Disclosure Regulation in Online Social Network Sites, „Bulletin of Science, Technology \& Society” 2008, Vol. 28, No. 1, s. 20-36.

Turkle Sherry, Alone Together. Why We Expect More from Technology and Less from Each Other, New York 2011.

Urry John, Mobility and proximity, „Sociology” 2002, Vol. 36, No. 2, s. 255-274. Wanke Michał, Internet i nowe indywidualne i masowe formy uczestnictwa [online]. Slideshare [dostęp 31 maja 2014]. Dostępny w World Wide Web: http:// www.slideshare.net/wankz/internet-i-nowe-indywidualne-i-masoweformy-uczestnictwa. 


\title{
New Media and Technologies of Identity. Lifestreaming as a Socio-cultural Practice
}

\begin{abstract}
The paper is devoted to a theoretical analysis of the phenomenon of lifestreaming - a specific socio-cultural practice embedded in the reality of new communication technologies. To lifestream means to leave digital traces of self online, broadcast self-related content, (auto)explore one's identity presenting it at the same time to a networked audience. Due to affordances of new communication technologies their users have the opportunity to share with others diverse content as well as manage their presence in social networking platforms in the realm of mobile media. The paper analyzes both the analytical background and the social context of the depicted practice as well as potential future scenarios of the evolution of the phenomenon researched today by social scientists.
\end{abstract}

KEYWORDS: lifestreaming; new communication technologies; reality mining; reedition of Self. 
